\title{
Effective microbial disinfection in food industry with hydroxyl radical fumigation
}

\author{
${ }^{1, *}$ Sangadkit, W. and ${ }^{2}$ Kongtrub, J. \\ ${ }^{1}$ Food Safety Management, Fermentation Technology Division, Faculty of Food Industry, King Mongkut's \\ Institute of Technology Ladkrabang, Chalong Krung Rd, Bangkok 10520, Thailand \\ ${ }^{2}$ Department of Biochemistry, Faculty of Science, Burapha University, 169 Long-Hard Bangsaen Road, \\ Saensook, Muang, Chon Buri 20131, Thailand
}

\begin{abstract}
Article history:
Received: 27 May 2020

September 2020

Available Online: 20

December 2020

Keywords:

Surface disinfection,

Hydrogen peroxide,

Fumigation,

Ozone,

Ultraviolet
\end{abstract}

Received in revised form: 23

Accepted: 7 December 2020

DOI:

https://doi.org/10.26656/fr.2017.4(S4).010

\begin{abstract}
Hydrogen peroxide $\left(\mathrm{H}_{2} \mathrm{O}_{2}\right)$ fumigation has recently been explored and tested to be a good fumigant replacement of formaldehyde. This technique has been proven safer, less irritating and requires shorter exposure times. Surface disinfection has long been implemented with toxic formaldehyde or $35 \%$ hydrogen peroxide $\left(\mathrm{H}_{2} \mathrm{O}_{2}\right)$. The results showed that they could be replaced with a safer and stronger oxidizing agent, activated $\mathrm{H}_{2} \mathrm{O}_{2}$ in a vaporized form. Aerosolization by aerosol generators has been used to produce aerosols containing hydroxyl radicals of hydrogen peroxide. The dispersal of this highly oxidizing mist of micron-size droplets destroyed Escherichia coli and Aspergillus niger colonies that have been artificially spiked on surfaces. The experiments demonstrated efficient disinfection by integrating 1 to $5 \% \mathrm{H}_{2} \mathrm{O}_{2}$ fumigation with ozone $\left(\mathrm{O}_{3}\right)$ and ultraviolet light (UV-C). Studies with E. coli and A. niger showed some disinfection with either $\mathrm{O}_{3}$ or UV-C. Combining $\mathrm{H}_{2} \mathrm{O}_{2}$ fumigation with both $\mathrm{O}_{3}$ and UV-C exposure considerably accelerated the microbial inactivation. This approach allowed fast disinfection with 1 to $5 \% \mathrm{H}_{2} \mathrm{O}_{2}$ while offering cheaper and safer disinfection for healthcare settings.
\end{abstract}

\section{Introduction}

Bacterial and mold contamination in food industries provided poor hygiene practices that likely contribute to infectious disease outbreaks. High bacterial contamination on any food processing areas can signify poor sanitation practices and generate detrimental consequences on human health. Possibly a few of these microbes may act as human pathogens or instigate allergic reactions ( $\mathrm{Wu}$ et al., 2016). Poor hygiene and improper food preparation practices had previously been demonstrated as contributing to many foodborne diseases and outbreaks (Erickson et al., 2015). At the presence of high microbial counts, cross-contamination permitted the transfer of microorganisms (bacteria, virus, parasites, or fungi) from one contaminated area to the other. Unfortunately, people in the food supply chain occasionally have little awareness of surfaces and equipment with high microbial contamination, which are unable to detect by simple visual inspection and take several hours to days to validate (Erickson et al., 2015). Unsanitized processes or areas post a high risk to the transmission and the occurrence of sporadic foodborne outbreaks. Thorough sanitizing of food processing surfaces and areas serve as an effective precaution to prevent the chance of cross-contamination and eliminate the risk for humans to ingest contaminated food and become ill. The highly effective antimicrobial activity but minimal toxicity of the residual chemical (e.g., organic acids, chlorine dioxide, hydrogen peroxide, and ozonated water) have been done to find alternative aqueous sanitizers. (Huang and Chen, 2011; Kingsley et al., 2014). Traditionally, fumigation with formaldehyde has been used to disinfect indoor areas, but formaldehyde is toxic and harmful for humans and the environment (CDC, 2008). Alternatively, replacing formaldehyde with hydrogen peroxide is proven to be safer and require shorter contact times (Krause et al., 2001; Kahnert et al., 2005). For example, vaporized hydrogen peroxide (VHP) has widely been used to remove casual agents in healthcare settings. However, VHP requires a high concentration of hydrogen peroxide (typically, >35\%), which must be used with extreme caution with respect to contact the skin or eyes (Kimura, 2012). Instead of VHP, this work explored fumigation at 1 to $5 \% \mathrm{H}_{2} \mathrm{O}_{2}$. The $\mathrm{H}_{2} \mathrm{O}_{2}$ solution was dispersed into 
aerosols with ultrasonic transducers. Additional treatments with $\mathrm{O}_{3}$ and/or UV-C were studied systematically. These treatments have been reported to activate the generation of hydroxyl $(\mathrm{OH} \cdot)$ radicals, which are typically more oxidizing than $\mathrm{H}_{2} \mathrm{O}_{2}$ molecules (Kimura, 2012). This paper had sheds light on disinfection technology that integrates ozonation and photolysis to produce highly oxidizing agents from $\mathrm{H}_{2} \mathrm{O}_{2}$, for fast-acting effect. This allows the disinfection to take place at low concentration of $\mathrm{H}_{2} \mathrm{O}_{2}$ to reduce the material cost as well as the toxicity of condensate residues.

\section{Materials and methods}

\subsection{Strains and culture media}

E. coli DMST 4609 and A. niger ATCC 44310 were used to test for bacteria and mold inactivation, respectively. The stock cultures were then kept in Tryptic Soy Broth, TSB (Lab M, UK), containing 20\% glycerol and stored at $-18^{\circ} \mathrm{C}$. Prior to use, the bacterial and mold stocks were grown in TSB for $18-24 \mathrm{~h}$ at $37{ }^{\circ} \mathrm{C}$ and Potato Dextrose Broth, PDB (Lab M, UK) for 5 days at $30^{\circ} \mathrm{C}$, respectively.

\subsection{Growth conditions and viable counts}

The testing strains were aseptically transferred into the surface of corresponding agar media in the mini Petri dish format. Plate Count Agar (PCA, Difco, USA) and Potato Dextrose Agar (PDA, Lab M, UK) were used to cultivate $E$. coli and A. niger colonies, respectively. Each inoculation volume contained $30 \mu \mathrm{L}$ of the strain sample at $10^{4} \mathrm{CFU} / \mathrm{cm}^{2}$ and spread over the agar surface with a glass rod.

\subsection{Fumigation setup}

The generation of $\mathrm{OH} \cdot$ was achieved using a patentpending technology Thailand-1701000719, initiated by the mixing of $\mathrm{O}_{3}$ and $\mathrm{H}_{2} \mathrm{O}_{2}$ solution using a Venturi mixer (Rano Tech Co., Ltd, Thailand). $\mathrm{O}_{3}$ was produced by feeding oxygen gas at flow rates $2 \mathrm{~L} / \mathrm{min}$ through the $\mathrm{O}_{3}$ tube $\left(7 \mathrm{~g} / \mathrm{L}\right.$ air-cooled ceramic $\mathrm{O}_{3}$ tubes (Arinnovation, Thailand). The circulation of $\mathrm{OH} \cdot$ and $\mathrm{H}_{2} \mathrm{O}_{2}$ was photocatalyzed by 4 UV-C lamps with 15 watts per unit located after a circulation pump to further activate more free radicals in the system. The total working volume of this system was $10 \mathrm{~L}$ where three piezoelectric transducers $(133 \mathrm{~mL} / \mathrm{h}$ vaporization rate) was installed inside to create instant $\mathrm{OH}$ - fume. Forced convection by a $5 \mathrm{~W}$ fan carried the generated fume via a conduit discharging to the bottom chamber inlet. The fume distribution inside the chamber was monitored by the $\%$ RH change using two data loggers (top and bottom dataloggers). The excess fume escaped the chamber through the outlet opening. The inoculated plates were installed face-down at the top and the sides of a testing chamber $\left(34 \times 34 \times 34 \mathrm{~cm}^{3}\right)$. In the setup (shown in Figure 1), $\mathrm{H}_{2} \mathrm{O}_{2}$ solution and $\mathrm{O}_{3}$ were mixed at a venturi mixer to generate the hydroxyl $(\mathrm{OH} \cdot)$ radicals. The mixture was flowed through a reservoir that contained a piezoelectric transducer and a fan to deliver the fume to the testing chamber. In some scenarios, the mixture also flowed through the UV-C sterilizer.

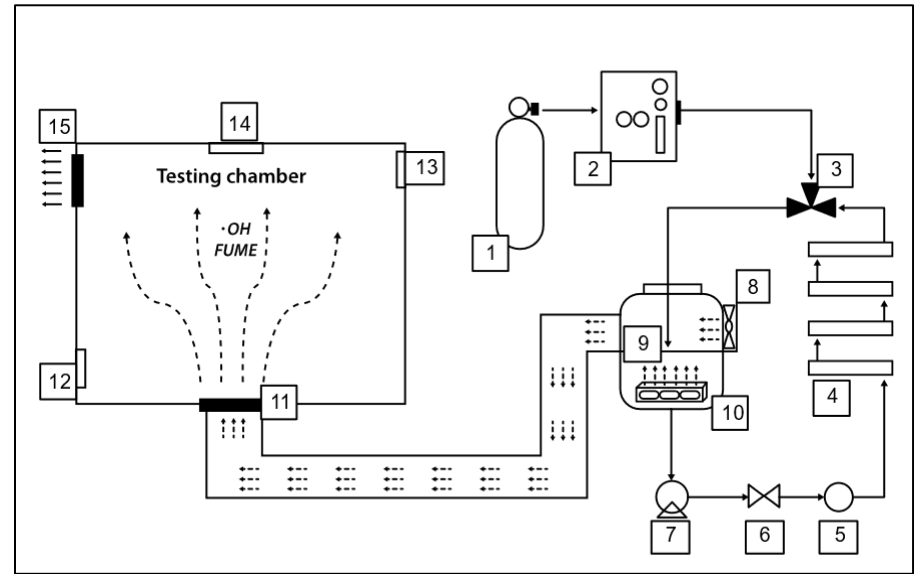

Figure 1. Schematic diagram of a $34 \times 34 \times 34 \mathrm{~cm}^{3}$ testing chamber connected to the $\mathrm{OH} \cdot$ aerosolization system consisting of (1) oxygen tank, (2) ozone generator, (3) venturi mixer, (4) UV-C lamps, (5) flow meter, (6) flow control valve, (7) water pump, (8) fan, (9) piezoelectric transducers, (10) holding reservoir, (11) chamber inlet, (12) bottom data-logger, (13) top data-logger, (14) inoculated plate, (15) chamber outlet.

\subsection{Fumigation experiments}

The inoculated agar plates at $10^{4} \mathrm{CFU} / \mathrm{cm}^{2}$ in each strain ( $E$. coli and $A$. niger) were attached to the top and side surfaces of the chamber. There were 10 plates in each treatment for testing the disinfection efficiency. The concentration of $\mathrm{H}_{2} \mathrm{O}_{2}$ solution was varied from 1,3 , and $5 \%$. The treatments consisted of $\mathrm{H}_{2} \mathrm{O}_{2}$ combined with $\mathrm{O}_{3}$, UV-C, and $\mathrm{O}_{3}$ with UV-C at different concentration of $\mathrm{H}_{2} \mathrm{O}_{2}$. The fumigation times were varied at $0,2,4,6,8$, $10,12,14$, and 16 mins in order to demonstrate any differences in their ability to kill bacteria and mold on the surface of the inoculated plates. The viable cell count after fumigation in each time was performed by incubating the inoculated plates in the oven at $37^{\circ} \mathrm{C}$ for overnight for $E$. coli and 5-7 days at $30^{\circ} \mathrm{C}$ for A. niger. The colonies at different fumigation times were counted as followed:

$\log (($ number of colonies * dilution factor $) /($ area of petri dish plate)) 


\subsection{Empirical model for disinfection kinetics}

To compare the inactivation between the different experiments (i.e., $1 \% \mathrm{H}_{2} \mathrm{O}_{2}, 1 \% \mathrm{H}_{2} \mathrm{O}_{2}$ and $\mathrm{O}_{3}, 1 \% \mathrm{H}_{2} \mathrm{O}_{2}$ and UV-C, and $1 \% \mathrm{H}_{2} \mathrm{O}_{2}, \mathrm{O}_{3}$, and UV-C) as described the materials and methods above, the results were fitted to a modified Chick-Watson equation (Cho et al., 2013) using nonlinear least-square solver in MATLAB ${ }^{\circledR}$ (tolerance $=10^{-6}$ ). Log-Linear model has been widely accepted and used to describe the microbial inactivation resulted from the application of both thermal and nonthermal processes. Based on the results, it was observed that the curve of the E. coli reduction profiles and the treatment times both were in accordance as determined using the pseudo-first-order model. Generally, this model assumes the death rate of microorganisms, which follows the rules for first-order kinetics. Moreover, this model is widely used to assess the effect of a wide array of processing factors such as UV-C, Ozone treatments, etc., on microbial inactivation (Ochoa-Velasco et al., 2020). Therefore, this model was used to predict the pseudofirst order kinetics and accounted for the tail at the end. Moreover, the first-order kinetics model is advantageous in evaluating the effect of various treatments on foodborne microbes based on its suitability and simplicity.

Where $C / C_{0}=$ the reduction in the bacterial or mold concentration at time $(\mathrm{t}), \mathrm{k}_{1}=$ the inactivation rate constant $\left(\mathrm{min}^{-1}\right)$ and $\mathrm{k}_{2}=$ the first order decay constant $\left(\min ^{-1}\right)$.

$$
\log \frac{\mathrm{C}}{\mathrm{C}_{\mathrm{o}}}=-k_{1}\left[1-\exp \left(-k_{2} t\right)\right]
$$

The empirical kinetic parameters were summarized in Table 1. These parameters were used to plot model lines in Figure 2.

\subsection{Statistical Analysis}

All statistical analysis was performed with SPSS 20.0 (SPSS Inc., Chicago, 1L). Differences between treatments were determined by analysis of variance (ANOVA). The significant difference was designed at $\mathrm{P}$ $<0.05$.

Table 1. Rate constants for the inactivation of E. coli and A. niger under different conditions obtained using the modified ChickWatson model. These parameters were used to plot model lines in Figure 2.

\begin{tabular}{lcccccc}
\hline \multirow{2}{*}{ Treatments } & \multicolumn{3}{c}{ E. coli } & \multicolumn{3}{c}{ A. niger } \\
\cline { 2 - 7 } & $\mathrm{k}_{1}\left(\mathrm{~min}^{-1}\right)$ & $\mathrm{k}_{2}\left(\mathrm{~min}^{-1}\right)$ & $\mathrm{R}^{2}$ & $\mathrm{k}_{1}\left(\mathrm{~min}^{-1}\right)$ & $\mathrm{k}_{2}\left(\mathrm{~min}^{-1}\right)$ & $\mathrm{R}^{2}$ \\
\hline $1 \% \mathrm{H}_{2} \mathrm{O}_{2}$ & $35.20 \pm 0.18^{\mathrm{a}}$ & $0.0004 \pm 0.0120^{\mathrm{c}}$ & 0.95 & $4.31 \pm 0.24^{\mathrm{a}}$ & $0.1810 \pm 0.0140^{\mathrm{b}}$ & 0.95 \\
$1 \% \mathrm{H}_{2} \mathrm{O}_{2}+\mathrm{O}_{3}$ & $12.20 \pm 0.10^{\mathrm{c}}$ & $0.0190 \pm 0.0080^{\mathrm{b}}$ & 0.96 & $4.00 \pm 0.10^{\mathrm{b}}$ & $5.0700 \pm 0.1190^{\mathrm{a}}$ & - \\
$1 \% \mathrm{H}_{2} \mathrm{O}_{2}+\mathrm{UV}-\mathrm{C}$ & $23.30 \pm 0.22^{\mathrm{b}}$ & $0.0070 \pm 0.0200^{\mathrm{c}}$ & 0.94 & $4.00 \pm 0.10^{\mathrm{b}}$ & $5.0700 \pm 0.1210^{\mathrm{a}}$ & - \\
$1 \% \mathrm{H}_{2} \mathrm{O}_{2}+\mathrm{O}_{3}+\mathrm{UV}-\mathrm{C}$ & $3.99 \pm 0.16^{\mathrm{d}}$ & $0.6600 \pm 0.1120^{\mathrm{a}}$ & 0.90 & $4.00 \pm 0.12^{\mathrm{b}}$ & $5.0700 \pm 0.0912^{\mathrm{a}}$ & - \\
\hline
\end{tabular}

Values in the columns with different superscripts mean that the values are significantly different $(\mathrm{p}<0.05)$ 


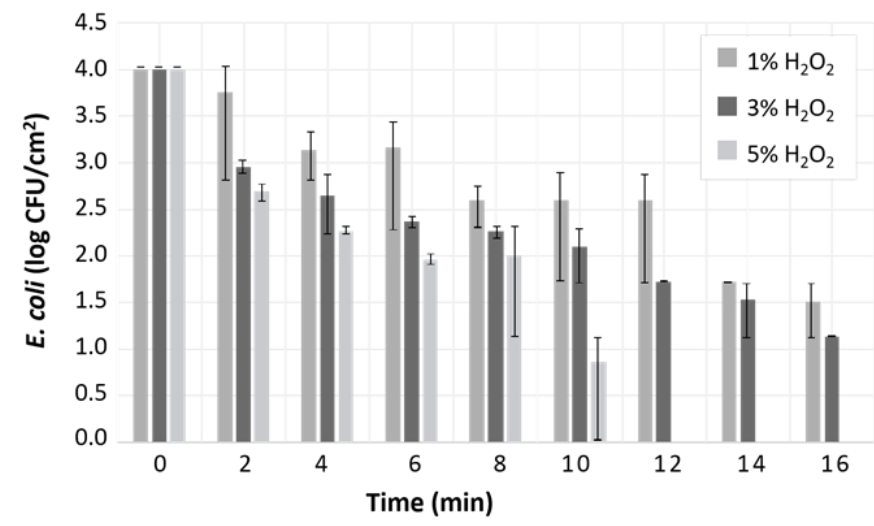

Figure 3. E. coli colony counts after treating with $\mathrm{H}_{2} \mathrm{O}_{2}$ fumes at different times by using different $\mathrm{H}_{2} \mathrm{O}_{2}$ concentrations $(1 \%$, $3 \%$, and $5 \%$ ). Each bar represents mean \pm SEM, $n=10$

and $5 \% \mathrm{H}_{2} \mathrm{O}_{2}$ ). The ultrasonic transducer was able to energize $\mathrm{H}_{2} \mathrm{O}_{2}$ solution and successfully create stream of $\mathrm{H}_{2} \mathrm{O}_{2}$ aerosols producing substantial microbial reduction within 15 mins. Increasing the antimicrobial agent concentration generally improved the effectiveness of the treatment. With the $4 \log \mathrm{CFU} / \mathrm{cm}^{2}$ of the initial E. coli contamination, only $5 \% \quad \mathrm{H}_{2} \mathrm{O}_{2}$ fume enabled total disinfection of the spiked surfaces within 12 mins whereas the lower concentrations (i.e., $1 \%$ and $3 \% \mathrm{H}_{2} \mathrm{O}_{2}$ ) were unable to produce complete sterility. From the results of $A$. niger survivability, this $\mathrm{H}_{2} \mathrm{O}_{2}$ fumigation was more effective towards mold inactivation than the bacteria. Because it has been reported that, the commercial vaporized $\mathrm{H}_{2} \mathrm{O}_{2}$ fume system is highly effective to rapidly oxidize fungal vegetative forms and spores than bacterial spores (Sandle, 2006). Often time, fungal spores are less resistant than bacterial spores. For mold, the $\mathrm{H}_{2} \mathrm{O}_{2}$ fume as low as $1 \% \mathrm{H}_{2} \mathrm{O}_{2}$ was able to eliminate artificial $A$. niger contamination within 10 mins where the same $\mathrm{H}_{2} \mathrm{O}_{2}$ fume only produced $20-25 \%$ inactivation of $E$. coli on the normalized scale. A higher concentration of $\mathrm{H}_{2} \mathrm{O}_{2}$ fume (i.e., $5 \% \mathrm{H}_{2} \mathrm{O}_{2}$ ) shortened the treatment time to 4 mins. Seemingly, mold was more susceptible to this low-concentration $\mathrm{H}_{2} \mathrm{O}_{2}$ fumigation than bacteria. The inactivation kinetics was studied using different $\mathrm{H}_{2} \mathrm{O}_{2}$ concentrations, without $\mathrm{O}_{3}$ or UV-C treatment. Under this condition, the result found that the bacteria were inactivated less effectively than the mold. With $5 \% \mathrm{H}_{2} \mathrm{O}_{2}$, the total disinfection time for the bacteria and the mold were 12 and 4 mins, respectively. In line with previous work (Raffellini, 2008), at higher concentrations of $\mathrm{H}_{2} \mathrm{O}_{2}$ observed greater bacterial inactivation.

\subsection{Effect of ozonation on the activity of $\mathrm{H}_{2} \mathrm{O}_{2}$ fumigation}

In this experiment, the efficacy of $\mathrm{H}_{2} \mathrm{O}_{2}$ fumigation was enhanced by applying ozonation to excite the formation of free radicals. Figures 5-7 show that E. coli destruction was improved by coupling $\mathrm{H}_{2} \mathrm{O}_{2}$ fumigation with ozonation. The total disinfection of $E$. coli with $\mathrm{O}_{3}$

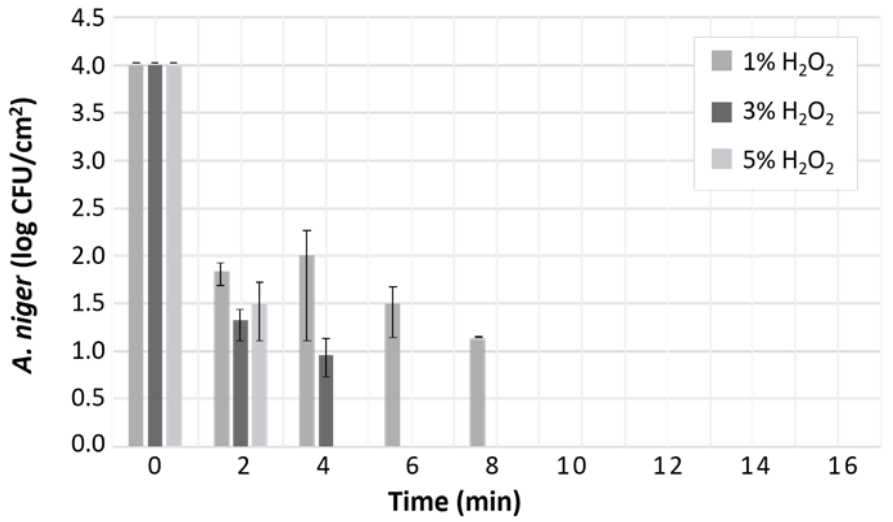

Figure 4. A. niger colony counts after treating with $\mathrm{H}_{2} \mathrm{O}_{2}$ fumes at different times by using different $\mathrm{H}_{2} \mathrm{O}_{2}$ concentrations $(1 \%$, $3 \%$, and $5 \%$ ). Each bar represents mean \pm SEM, $n=10$

happened earlier than the ones without $\mathrm{O}_{3}$. This effect was even more prominent in the experiment with $A$. niger. It required less than 2 mins for total disinfection of A. niger at all $\mathrm{H}_{2} \mathrm{O}_{2}$ concentrations (Figure 8-10). When the ozonation application, the synergy between the $\mathrm{H}_{2} \mathrm{O}_{2}$ fumigation with ozonation produced significant cells reduction via the generation of $\bullet \mathrm{OH}$ and enabled the reduction of both E. coli and A. niger. Presumably, the mechanism for the photolysis of $\mathrm{H}_{2} \mathrm{O}_{2}$ is the cleavage of the molecule into two $\mathrm{OH} \bullet$. Also, $\mathrm{O}_{3}$ can combine with

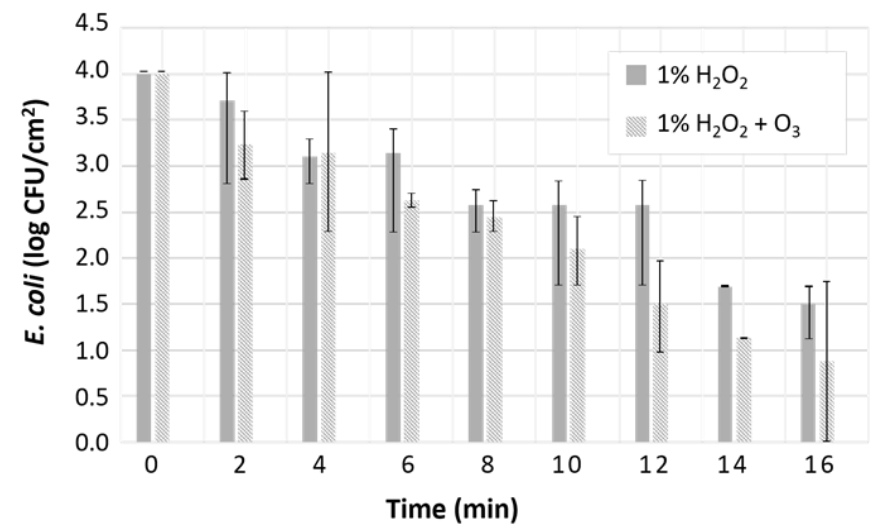

Figure 5. E. coli colony counts after treating with two different treatments at different times by using $1 \% \quad \mathrm{H}_{2} \mathrm{O}_{2}$ versus $1 \% \mathrm{H}_{2} \mathrm{O}_{2}+\mathrm{O}_{3}$. Each bar represents mean $\pm \mathrm{SEM}, \mathrm{n}=$ 10

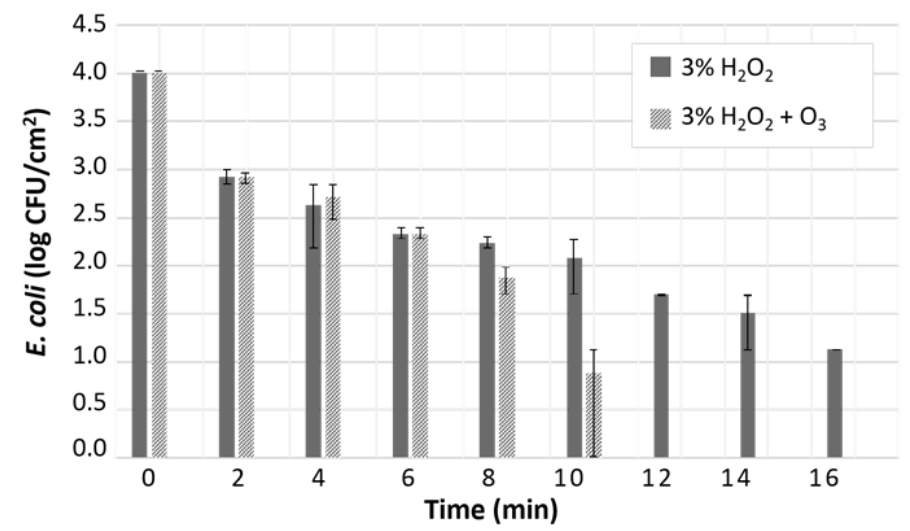

Figure 6. E. coli colony counts after treating with two different treatments at different times by using $3 \% \mathrm{H}_{2} \mathrm{O}_{2}$ versus $3 \%$ $\mathrm{H}_{2} \mathrm{O}_{2}+\mathrm{O}_{3}$. Each bar represents mean $\pm \mathrm{SEM}, \mathrm{n}=10$ 
$\mathrm{H}_{2} \mathrm{O}_{2}$ solution to enhance the transformation of $\mathrm{O}_{3}$ and $\mathrm{H}_{2} \mathrm{O}_{2}$ to $\mathrm{OH} \bullet$ in $\mathrm{OH} \cdot$ mist. Even in $1 \% \mathrm{H}_{2} \mathrm{O}_{2}$, the combined effects of $\mathrm{H}_{2} \mathrm{O}_{2}$ and ozonation were able to harness enough $\bullet \mathrm{OH}$. Then $\mathrm{H}_{2} \mathrm{O}_{2}$ at $5 \%$ was added to increase the substrate to generate $\cdot \mathrm{OH}$ (Hoigne, 1998) and a significant improvement in the efficacy of bacterial reduction was achieved. The addition of $\mathrm{H}_{2} \mathrm{O}_{2}$ to the $\mathrm{O}_{3}$ process accelerates the decomposition of $\mathrm{O}_{3}$, which results in an increased rate of $\mathrm{OH} \bullet$ generation.

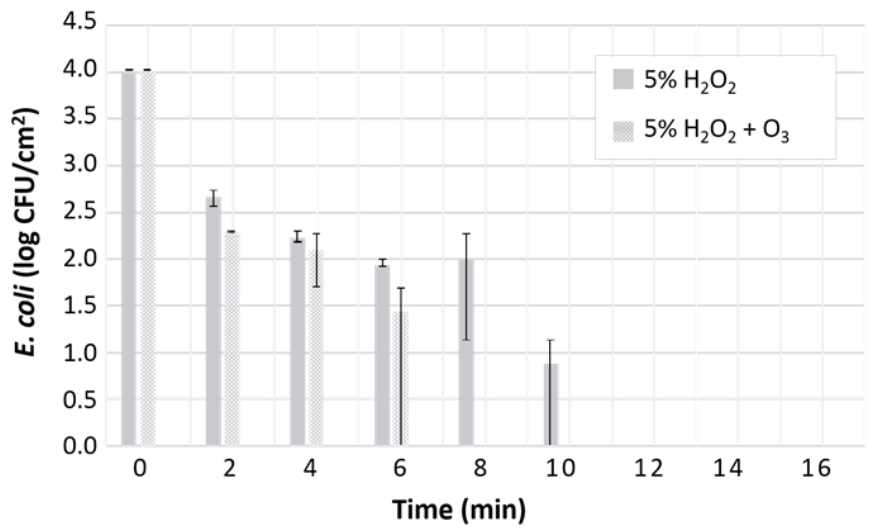

Figure 7. E. coli colony counts after treating with two different treatments at different times by using $5 \% \quad \mathrm{H}_{2} \mathrm{O}_{2}$ versus $5 \% \mathrm{H}_{2} \mathrm{O}_{2}+\mathrm{O}_{3}$. Each bar represents mean $\pm \mathrm{SEM}, \mathrm{n}=$ 10

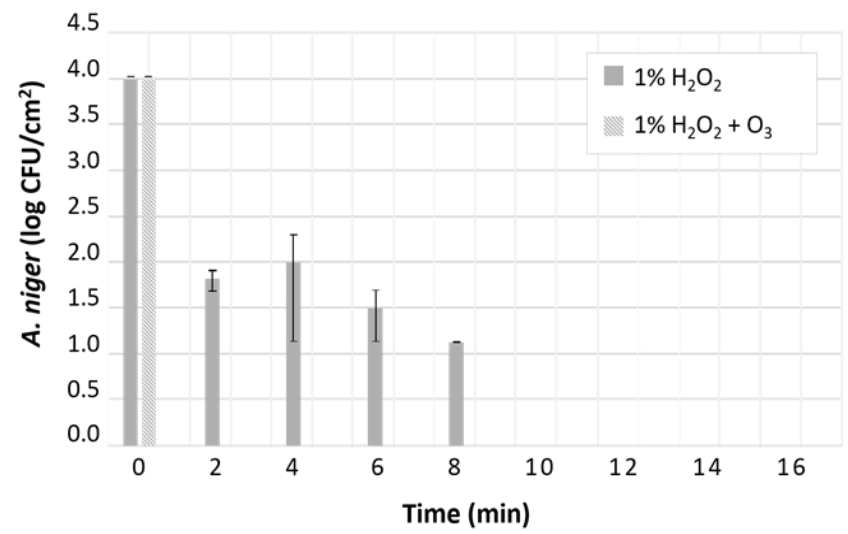

Figure 8. A. niger colony counts after treating with two different treatments at different times by using $1 \% \mathrm{H}_{2} \mathrm{O}_{2}$ versus $1 \% \mathrm{H}_{2} \mathrm{O}_{2}+\mathrm{O}_{3}$. Each bar represents mean $\pm \mathrm{SEM}, \mathrm{n}=$ 10

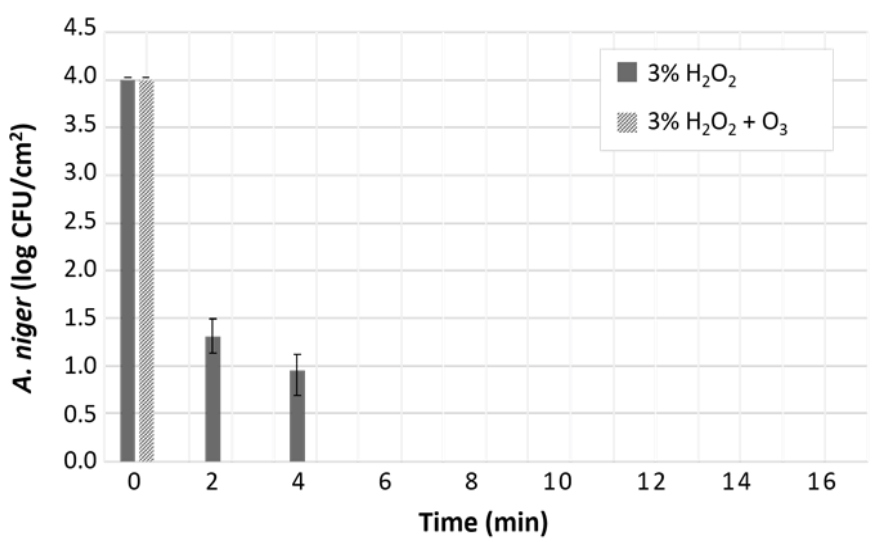

Figure 9. A. niger colony counts after treating with two different treatments at different times by using $3 \% \quad \mathrm{H}_{2} \mathrm{O}_{2}$ versus $3 \% \mathrm{H}_{2} \mathrm{O}_{2}+\mathrm{O}_{3}$. Each bar represents mean $\pm \mathrm{SEM}, \mathrm{n}=$ 10

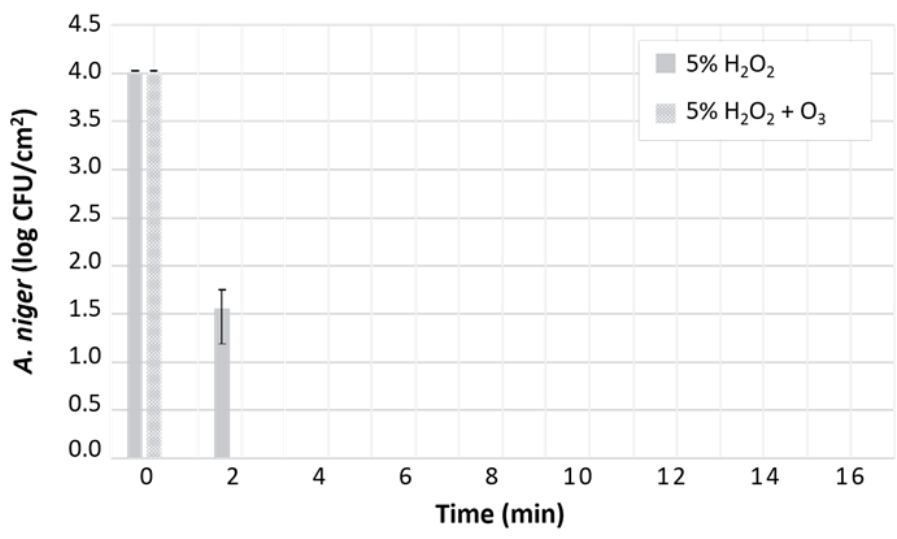

Figure 10. A. niger colony counts after treating with two different treatments at different times by using $5 \% \quad \mathrm{H}_{2} \mathrm{O}_{2}$ versus $5 \% \mathrm{H}_{2} \mathrm{O}_{2}+\mathrm{O}_{3}$. Each bar represents mean $\pm \mathrm{SEM}, \mathrm{n}=$ 10

3.3 Effect of photolysis on the activity of $\mathrm{H}_{2} \mathrm{O}_{2}$ fumigation

The $\mathrm{H}_{2} \mathrm{O}_{2}$ solution was exposed to UV-C light. For E. coli, the UV-C treatment does not significantly affect the inactivation kinetics of the $\mathrm{H}_{2} \mathrm{O}_{2}$ fumes. As shown in Figure 11-13, the $E$. coli concentration profile over time was similar to the $\mathrm{H}_{2} \mathrm{O}_{2}$ fumigation without UV-C. For A. niger, on the other hand, the disinfection of $A$. niger was improved by implementing the UV-C effect. Total disinfection of $A$. niger was somewhat instant ( $<2$ mins) at all concentrations of $\mathrm{H}_{2} \mathrm{O}_{2}$ as shown in Figure 14-16.

\subsection{Synergic effects of photolytic ozonation at 3\% and} $5 \% \mathrm{H}_{2} \mathrm{O}_{2}$ fumigation

By combining the effects of $\mathrm{O}_{3}$ and UV-C, the activity of $\mathrm{H}_{2} \mathrm{O}_{2}$ fumigation was greatly improved. Total disinfection of $E$. coli was possible within a short time as shown in Figure 17. This synergic effect was more difficult to observe in the A. niger experiment because individual treatment of $\mathrm{O}_{3}$ or UV-C was already sufficient to completely inactivate the A. niger (Figure 18).

\subsection{Individual effects of ozonation and photolysis}

The $\mathrm{H}_{2} \mathrm{O}_{2}$ fume was then subject to either $\mathrm{O}_{3}$ or UV$\mathrm{C}$ exposure in order to investigate how each influenced the activity of the $\mathrm{H}_{2} \mathrm{O}_{2}$ fumigation. Previous works provide evidence that these two treatments could initiate the formation of highly reactive hydroxyl radicals $\left(\mathrm{OH}^{\cdot}\right)$. With $1 \% \mathrm{H}_{2} \mathrm{O}_{2}$, the $E$. coli disinfection was found to be slightly affected by the UV-C exposure but significantly enhanced by $\mathrm{O}_{3}$. However, each treatment was still not effective enough to enable the total disinfection within the time studied (16 mins). In contrast, for the $A$. niger sample, each treatment $\left(\mathrm{O}_{3}\right.$ or UV-C) greatly improved the disinfection rate. The total disinfection time was reduced from 10 mins to 2 mins by treating with either 


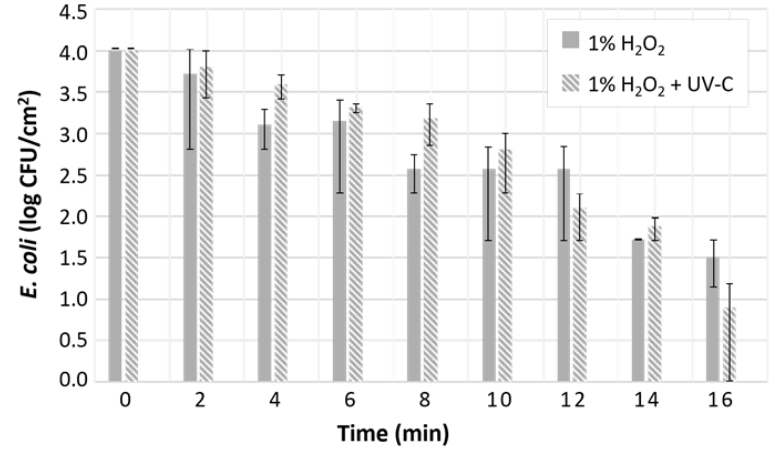

Figure 11. E. coli colony counts after treating with two different treatments at different times by using $1 \% \mathrm{H}_{2} \mathrm{O}_{2}$ versus $1 \% \mathrm{H}_{2} \mathrm{O}_{2}+$ UV-C. Each bar represents mean \pm SEM, $n$ $=10$

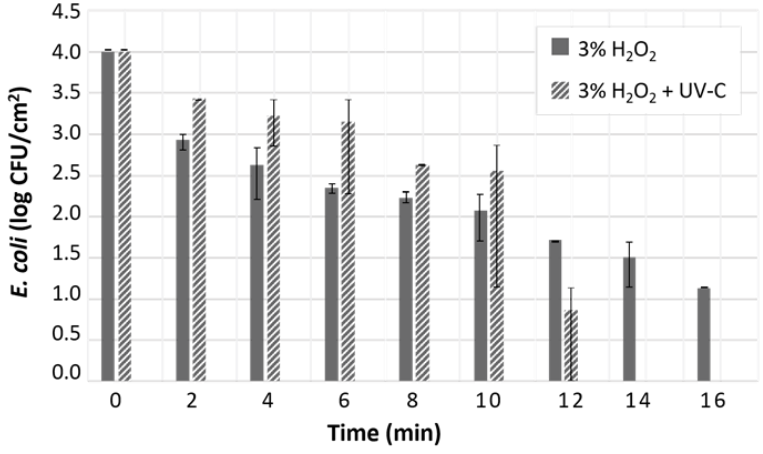

Figure 12. E. coli colony counts after treating with two different treatments at different times by using $3 \% \mathrm{H}_{2} \mathrm{O}_{2}$ versus $3 \% \mathrm{H}_{2} \mathrm{O}_{2}+$ UV-C. Each bar represents mean \pm SEM, $n$ $=10$

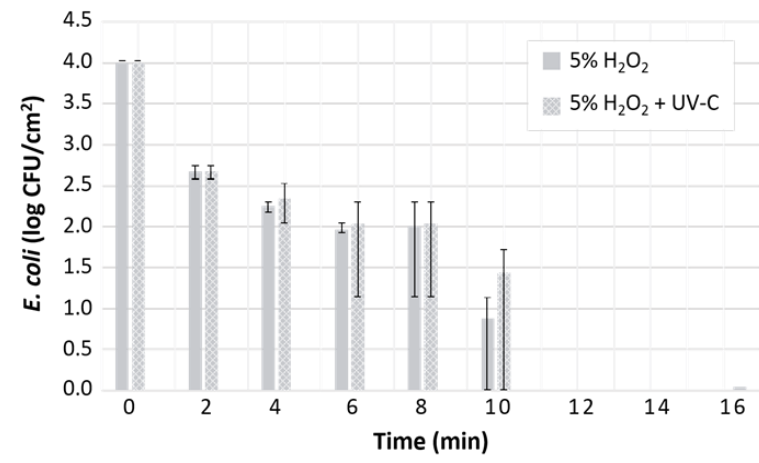

Figure 13. E. coli colony counts after treating with two different treatments at different times by using $5 \% \mathrm{H}_{2} \mathrm{O}_{2}$ versus $5 \% \mathrm{H}_{2} \mathrm{O}_{2}+$ UV-C. Each bar represents mean $\pm \mathrm{SEM}, \mathrm{n}$ $=10$

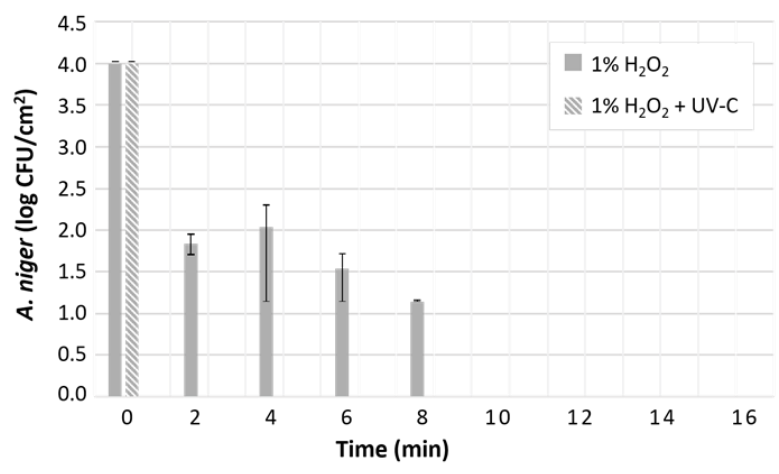

Figure 14. A. niger colony counts after treating with two different treatments at different times by using $1 \% \mathrm{H}_{2} \mathrm{O}_{2}$ versus $1 \% \mathrm{H}_{2} \mathrm{O}_{2}+\mathrm{UV}-\mathrm{C}$. Each bar represents mean $\pm \mathrm{SEM}, \mathrm{n}$ $=10$

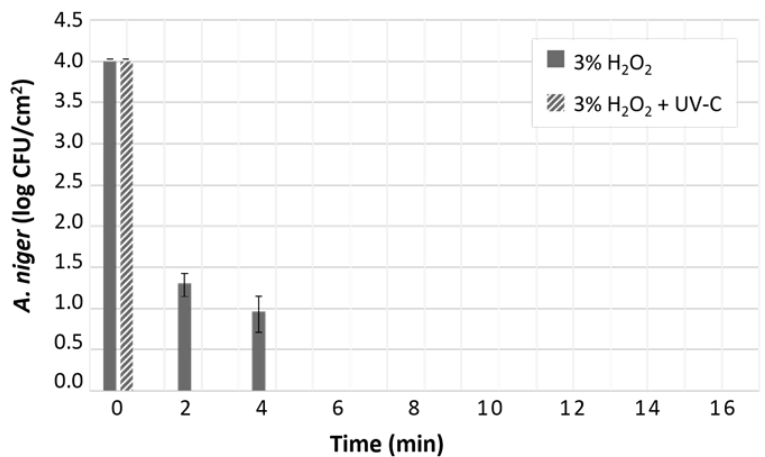

Figure 15. A. niger colony counts after treating with two different treatments at different times by using 3\% $\mathrm{H}_{2} \mathrm{O}_{2}$ versus $3 \% \mathrm{H}_{2} \mathrm{O}_{2}+$ UV-C. Each bar represents mean \pm SEM, $n$ $=10$

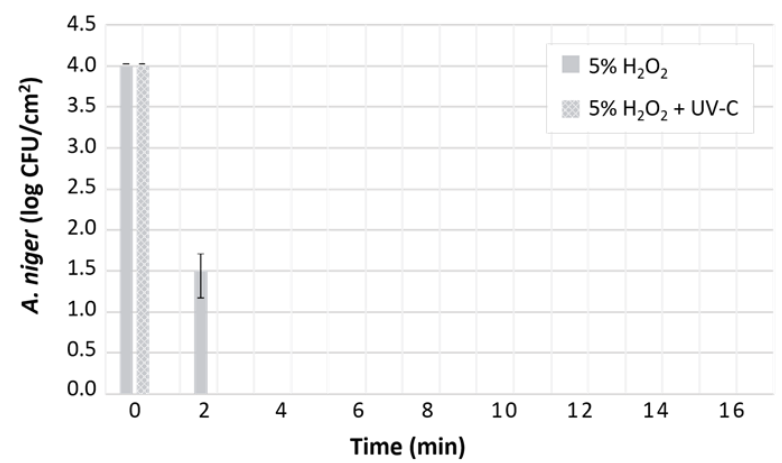

Figure 16. A. niger colony counts after treating with two different treatments at different times by using $5 \% \mathrm{H}_{2} \mathrm{O}_{2}$ versus $5 \% \mathrm{H}_{2} \mathrm{O}_{2}+\mathrm{UV}-\mathrm{C}$. Each bar represents mean $\pm \mathrm{SEM}, \mathrm{n}$ $=10$ 


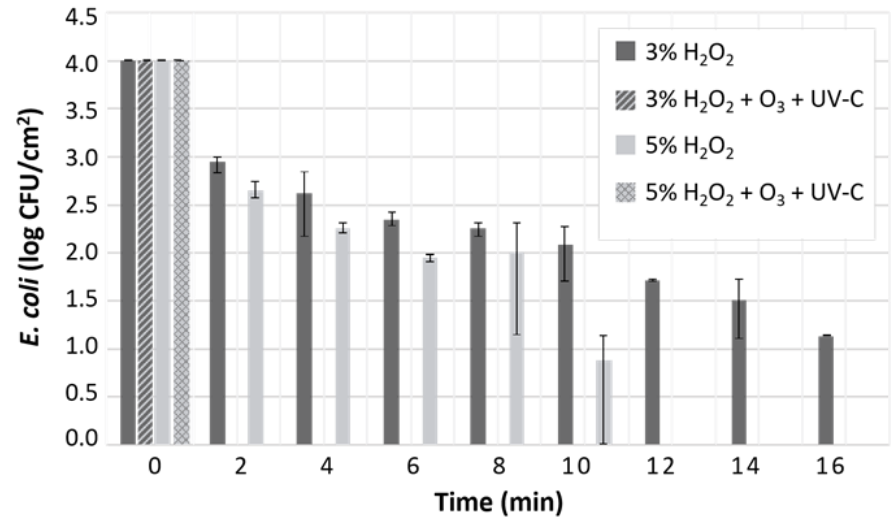

Figure 17. E. coli colony counts at different times after using two different treatments $\left(\mathrm{H}_{2} \mathrm{O}_{2}\right.$ versus $\left.\mathrm{H}_{2} \mathrm{O}_{2}+\mathrm{O}_{3}+\mathrm{UV}-\mathrm{C}\right)$ for two concentrations of $\mathrm{H}_{2} \mathrm{O}_{2}(3 \%$ and $5 \%)$. Each bar represents mean $\pm \mathrm{SEM}, \mathrm{n}=10$

$\mathrm{O}_{3}$ or UV-C alone.

\subsection{Synergic effect of photolytic ozonation}

In this subsequent experiment, both ozonation and photolysis were simultaneously applied to the $\mathrm{H}_{2} \mathrm{O}_{2}$ fumigation. Upon these conditions, the $\mathrm{k}_{1}$ and $\mathrm{k}_{2}$ values (Table 1) of E. coli were significantly different at any given treatments $(\mathrm{p}<0.05)$. The empirical parameters model in Table 1 (lines in Figure 2) was fitted to the results to demonstrate this effect. The linear model predicted a lower $\mathrm{k}_{1}$ and higher $\mathrm{k}_{2}$ values; it meant that E. coli was the least resistant strain to $1 \% \mathrm{H}_{2} \mathrm{O}_{2}$ combined with $\mathrm{O}_{3}$ and UV-C. At $1 \% \mathrm{H}_{2} \mathrm{O}_{2}$ combining the effects of $\mathrm{O}_{3}$ and UV-C, the total $E$. coli disinfection was completed within 6 mins as shown in Figure 2. Such synergic effect was not obvious in the $A$. niger experiment and treatments were not significantly affect the inactivation kinetics of the $\mathrm{H}_{2} \mathrm{O}_{2}$ fumes. Because any individual treatment, either $\mathrm{O}_{3}$ or UV-C, was already sufficient to disinfect ( $<2$ mins for $A$. niger).

\section{Discussion}

The disinfection with hydrogen peroxide alone resulted in slow disinfection since the $\mathrm{H}_{2} \mathrm{O}_{2}$ molecule is only mildly oxidizing with a low potential $(1.78 \mathrm{eV})$ (Zhou and Smith, 2002). One way to increase the inactivation kinetics is to decompose $\mathrm{H}_{2} \mathrm{O}_{2}$ into other more active oxidants such as $\mathrm{OH} \cdot$ radicals $(2.80 \mathrm{eV})$ (Zhou and Smith, 2002). Our results suggested that the use of $\mathrm{O}_{3}$ was more effective in doing this than UV-C photolysis. The mechanism for the photolysis of $\mathrm{H}_{2} \mathrm{O}_{2}$ is the cleavage of the $\mathrm{H}_{2} \mathrm{O}_{2}$ into two $\mathrm{OH}$. while the mechanism for the ozonation of $\mathrm{H}_{2} \mathrm{O}_{2}$ is less direct. In a weak acid solution, $\mathrm{H}_{2} \mathrm{O}_{2}$ partially dissociates into hydroperoxide ions $\left(\mathrm{HO}_{2}\right.$-). Ozonation can then rapidly convert $\mathrm{HO}_{2-}$ to $\mathrm{OH} \cdot$ (Hoigné, 1998). However, when both $\mathrm{O}_{3}$ and UV-C treatments were combined, the disinfection rate was considerably increased. The UV-C

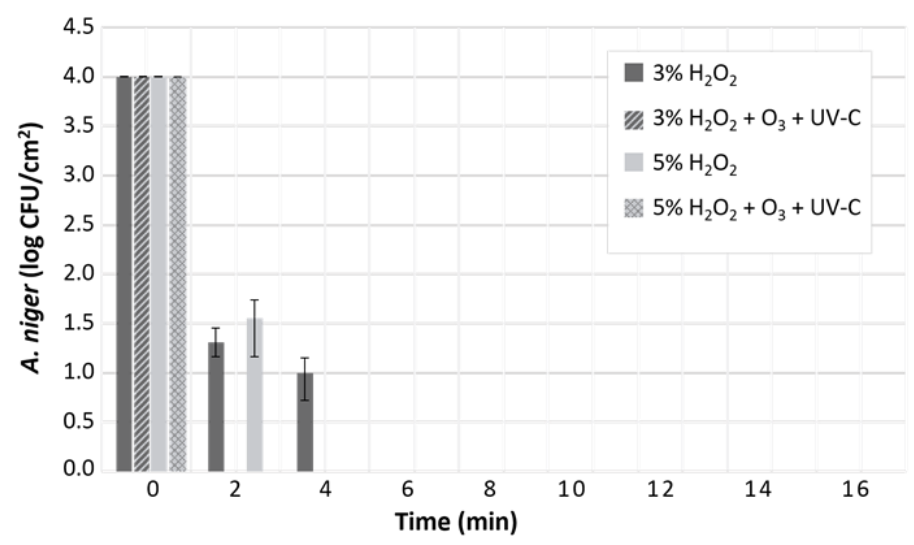

Figure 18. A. niger colony counts at different times after using two different treatments $\left(\mathrm{H}_{2} \mathrm{O}_{2}\right.$ versus $\left.\mathrm{H}_{2} \mathrm{O}_{2}+\mathrm{O}_{3}+\mathrm{UV}-\mathrm{C}\right)$ for two concentrations of $\mathrm{H}_{2} \mathrm{O}_{2}(3 \%$ and $5 \%)$. Each bar represents mean $\pm \mathrm{SEM}, \mathrm{n}=10$

light tends to activate several elementary reactions that generate more $\mathrm{OH} \cdot$ radicals (Munter, 2001). For example, under the UV-C light, the reaction between $\mathrm{O}_{3}$ and $\mathrm{H}_{2} \mathrm{O}_{2}$ to produce $\mathrm{OH}$ and $\mathrm{O}_{2}$ occurs. Therefore, when both $\mathrm{O}_{3}$ and UV-C were combined for the $\mathrm{H}_{2} \mathrm{O}_{2}$ fumigation, the total disinfection of bacteria and mold can be achieved at low $\mathrm{H}_{2} \mathrm{O}_{2}$ concentration within a short time. Upon total mineralization, the end products of complete oxidation are simply carbon dioxide and water. Similar to VHP, the residues after the fumigation have been reported to be safe (Krause et al., 2001). Therefore, this approach offers a promising alternative for disinfection in the food industry, hospitals, clinics, and other enclosed areas; it is fast, inexpensive, and safer.

\section{Conclusion}

In this research, the results presented the successful methodology for surface disinfection using hydrogen peroxide $\left(\mathrm{H}_{2} \mathrm{O}_{2}\right)$ fumigation in couple with ozonation and UV photolysis. Oxidizing agents have been widely used in food industry, hospitals and clinics for cleaning, yet existing methods have some disadvantages. For example, vaporized hydrogen peroxide (VHP) requires high concentration of $\mathrm{H}_{2} \mathrm{O}_{2}$. In this work, a system that produces aerosols of $\mathrm{H}_{2} \mathrm{O}_{2}$ solution to inactivate the microorganisms was developed. Exposure of the fumes to either ozone or UV light has found to enhance the rate of disinfection. When combining both ozone and UV effects to the fumigation system, the disinfection was the most efficient, making it possible to clean the surface totally within a very short time and with a low concentration of $\mathrm{H}_{2} \mathrm{O}_{2}$.

\section{Conflict of interest}

There is no conflict of interest declared 


\section{Acknowledgements}

The author gratefully acknowledge funding of this research by King Mongkut's Institute of Technology Ladkrabang Research Fund (Grant No.KREF186321).

\section{References}

Cho, M., Chung, H. and Yoon, J. (2013). Disinfection of water containing natural organic matter by using ozone-initiated radical reactions. Applied and Environmental Microbiology, 69, 2284-2291. https:// doi.org/10.1128/AEM.69.4.2284-2291.2003

Erickson, M.C., Liao, J., Cannon, J. and Ortega, Y.R. (2015). Contamination of knives and graters by bacterial foodborne pathogens during slicing and grating of produce. Food Microbiology, 52, 138-145. https://doi.org/10.1016/j.fm.2015.07.008

Hoigné, J. (1998). Chemistry of aqueous ozone and transformation of pollutants by ozonation and advanced oxidation processes. In Hrubec, J. (Ed.). Quality and treatment of drinking water II, p. 83141. Heidelberg, Berlin, Germany: Springer. https:// doi.org/10.1007/978-3-540-68089-5_5

Huang, Y. and Chen, H. (2011). Effect of organic acids, hydrogen peroxide and mild heat on inactivation of Escherichia coli O157: H7 on baby spinach. Food Control, 22(8), 1178-1183. https://doi.org/10.1016/ j.foodcont.2011.01.012

Kahnert, A., Seiler, P., Stein, M., Aze, B., McDonnell, G. and Kaufmann, S.H. (2005). Decontamination with vaporized hydrogen peroxide is effective against Mycobacterium tuberculosis. Letter in Applied Microbiology, 40(6), 448-452. https:// doi.org/10.1111/j.1472-765X.2005.01683.x

Kimura, T. (2012). Effective decontamination of laboratory animal rooms with vapour-phase ("Vaporized') hydrogen peroxide and peracetic acid. Scandinavian Journal of Laboratory Animal Sciences, 39, 17-23. https://doi.org/10.23675/ sjlas.v39i1.243

Kingsley, D.H., Vincent, E.M., Meade, G.K., Watson, C.L. and Fan, X. (2014). Inactivation of human norovirus using chemical sanitizers. International Journal of Food Microbiology, 171, 94-99. https:// doi.org/10.1016/j.ijfoodmicro.2013.11.018

Krause, J., McDonnell, G. and Riedesel, H. (2001). Biodecontamination of animal rooms and heatsensitive equipment with vaporized hydrogen peroxide. Journal of the American Association for Laboratory Animal Science, 40(6), 8-21.

Munter, R. (2001). Advanced oxidation processescurrent status and prospects. Proceedings of the Estonian Academy of Sciences Chemistry, 50(2), 59-
80.

Ochoa-Velasco, C., Ávila-Sosa, R., Hernández-Carranza, P., Ruíz-Espinosa, H., Ruíz -Espinosa, H., RuizLópez, I., Guerrero-Beltŕan, J. (2020). Mathematical modeling used to evaluate the effect of UV-C light treatment on microorganisms in liquid foods. Food Engineering Reviews, 12, 290-308. https:// doi.org/10.1007/s12393-020-09219-y

Raffellini, S., Guerrero, S. and Alzamora, S. (2008). Effect of hydrogen peroxide concentration and $\mathrm{pH}$ on inactivation kinetics of Escherichia coli. Journal of Food Safety, 28(4), 514-533. https:// doi.org/10.1111/j.1745-4565.2008.00128.x

Sandle, T. (2006). Risk of microbial spores to cleanrooms. Part 1: Introduction to microbial spores and survival mechanisms. Clean Air and Containment Review, 28, 4-6.

Wu, X., Han, C., Chen, J., Huang, Y.W. and Zhao, Y. (2016). Rapid detection of pathogenic bacteria from fresh produce by filtration and surface-enhanced raman spectroscopy, JOM, 68, 1156-1162. https:// doi.org/10.1007/s11837-015-1724-x

Zhou, H. and Smith, D.W. (2002). Advanced technologies in water and wastewater treatment. Journal of Environmental Engineering and Science, 1(4), 247-264. https://doi.org/10.1139/s02-020 